\title{
PENGARUH JENIS TEGAKAN TERHADAP KOMPOSISI DAN KEANEKARAGAMAN TUMBUHAN BAWAH DI HUTAN SAPEN KECAMATAN PRIGEN KABUPATEN PASURUAN
}

\author{
The Influence Of Several Plantation Forest Stands to Understories Composition and \\ Diversity at Sapen Forest, Prigen, Pasuruan
}

\author{
Roisatul Ainiyah ${ }^{1,}$ Amang Fathurraman ${ }^{1}$, Mulyono Wibisono ${ }^{2}$, \\ Fafit Rahmat Aji ${ }^{2}$, Diyono Yusuf ${ }^{3}$ \\ ${ }^{1}$ Universitas Yudharta Pasuruan \\ ${ }^{2}$ PT. Tirta Investama Pabrik Pandaan \\ ${ }^{3}$ Yayasan Satu Daun \\ Email: amangfr@yudharta.ac.id
}

\begin{abstract}
ABSTRAK
Penelitian keanekaragaman tumbuhan bawah dilakukan di Hutan Lindung Blok Sapen Kecamatan Prigen, Kabupaten Pasuruan. Penelitian ini bertujuan untuk mengetahui pengaruh jenis tegakan terhadap komposisi dan keanekaragaman tumbuhan bawah di Hutan Sapen. Terdapat tiga stasiun pengambilan sampel berdasarkan jenis tegakan yang ada, yaitu stasiun 1 (dibawah tegakan mahoni), stasiun 2 (dibawah tegakan pinus), dan stasiun 3 (tanpa tegakan). Pengambilan data dilakukan dengan menggunakan metode line transect. Dalam setiap stasiun pengamatan terdapat 70 plot pengamatan seluas $2 \times 2 \mathrm{~m}^{2}$ sepanjang jalur line transect. Jumlah total spesies yang ditemukan di tiga stasiun pengamatan adalah 137 spesies dari 43 famili. Keanekaragaman tumbuhan bawah di hutan Blok Sapen bedasarkan indeks keanekaragaman $\left(H^{\prime}\right)$ tertinggi ada pada stasiun $1(3,6518)$, kemudian stasiun 3 (tanpa tegakan) $(3,54775)$, dan stasiun 2 (2,988). Struktur dan komposisi tumbuhan bawah Berdasarkan INP, pada stasiun 1 lima urutan teratas tumbuhan bawah yang mendominasi adalah Paspalum conjugatum, Athyrium sp, Pasphalum commersonii, Centrocema pubescens, dan Adiantum sp. Pada stasiun 2 adalah Pasphalum commersonii, Imperata cylindrica, Centrocema pubescens, Pennisetum purpureum, dan Axonopus enapositus, dan pada stasiun 3 adalah Desmodium triflorum, Imperata cylindrica, Axonopus sp, Juwawutan, dan Mimosa pudica.

Jenis tegakan yang berbeda mempengaruhi iklim mikro yang berbeda pada lantai hutan, menyebabkan kondisi lingkungan $(\mathrm{pH}$, suhu, kelembapan tanah, kelembapan udara, dan intensitas cahaya) berbeda. Selain itu zat alelopati dan kecepatan dekomposisi serasah, juga berperan serta dalam menentukan komposisi dan keanekaragaman tumbuhan bawah.

Kata kunci : Hutan Sapen, jenis tegakan, komposisi dan keanekaragaman tumbuhan bawah.
\end{abstract}

\begin{abstract}
Research on the diversity of understorey was carried out in the Blok Sapen Protection Forest in Prigen District, Pasuruan Regency. This study aims to determine the effect of stand types on the composition and diversity of understorey in Sapen Forest. There are three sampling stations based on the types of stands, namely station 1 (under the mahogany stand), station 2 (under pine stands), and station 3 (without stands). Data retrieval is done using the line transect method. In each observation station there are 70 observation plots covering an area of $2 \times 2 \mathrm{~m} 2$ along the line transect line. The total number of species found in three observation stations was 137 species from 43 families. The diversity of understorey in the Sapen Block forest is based on the highest diversity index $\left(H^{\prime}\right)$ at station 1 (3.6518), then station 3 (without stand) (3,54775), and station 2 (2,988). Undergrowth structure and composition Based on the INP, at station 1 the top five top dominating plants are Paspalum conjugatum, Athyrium sp, Pasphalum commersonii, Centrocema pubescens, and Adiantum sp. At station 2 are Pasphalum commersonii, Imperata cylindrica, Centrocema pubescens, Pennisetum purpureum, and
\end{abstract}


Axonopus enapositus, and at station 3 are Desmodium triflorum, Imperata cylindrica, Axonopus sp, Juwawutan, and Mimosa pudica. Different types of stands affect different microclimates on the forest floor, causing different environmental conditions ( $\mathrm{pH}$, temperature, soil moisture, humidity, and light intensity). In addition allelopathic substances and the speed of decomposition of litter, also play a role in determining the composition and diversity of understorey.

Keywords: Sapen forest, stand type, composition and diversity of understorey.

\section{PENDAHULUAN}

Tumbuhan bawah adalah suatu tipe vegetasi dasar yang terdapat di bawah tegakan hutan kecuali permudaan pohon hutan, yang meliputi rerumputan, herba dan semak belukar. Dalam stratifikasi hutan hujan tropis, tumbuhan bawah menempati stratum D yakni lapisan perdu, semak dan lapisan tumbuhan penutup tanah pada stratum E (Soerianegara dan Indrawan 2008). Tumbuhan bawah yang ada di lantai hutan dapat menahan pukulan air hujan dan aliran permukaan sehingga mengurangi bahaya erosi. Tumbuhan bawah juga berperan dalam menjaga kesuburan tanah dengan menghasilkan serasah, tetapi bervariasi tergantung laju dekomposisi masingmasing serasah.

Hutan Blok Sapen (selanjutnya disebut dengan Hutan Sapen), merupakan salah satu hutan lindung yang dikelola oleh Perum Perhutani KPH Pasuruan. Hutan Sapen berada di lereng timur Gunung Arjuno di Petak 3 Perum Perhutani KPH Pasuruan seluas lebih kurang 20 hektar. Pengelolaan hutan lindung Blok Sapen oleh LMDH Leduk mengacu pada pengelolaan sistem tumpangsari pada hutan-hutan produksi dengan membudidaya tanaman pertanian dan tanaman pakan ternak (rumput gajah dan kaliandra).

Keberadaan hutan lindung ini menjadi hal yang penting terutama terkait fungsi konservasi dan penyangga tata hidrologi kawasan di sekitarnya. Keberadaan Hutan Sapen bisa berpotensi sebagai tempat penelitian dan pengembangan ilmu pengetahuan, keanekaragaman ekosistem baik flora maupun faunanya. Seiring dengan peningkatan populasi manusia, maka luas lahan yang dibutuhkannya pun semakin meningkat. Pembukaan lahan di dalam hutan adalah salah satu cara yang dilakukan oleh berberapa pihak untuk memenuhi kebutuhan tersebut. Hal ini juga dilakukan untuk tujuan lain seperti untuk lahan perkebunan dan industri kayu dan industri lain.

Pada tahun 2015 telah dilakukan penelitian keanekaragaman hayati flora dan fauna di Hutan Sapen. Wibisono 
(2016) dalam hasil penelitiannya menjelaskan bahwa ditemukan 17 jenis vegetasi tingkat tiang (poles) dan pohon (trees) di Hutan Sapen, yang didominasi oleh jenis-jenis pohon hasil budidaya yang termasuk pohon asing yaitu mahoni dan pinus, keduanya hampir menguasai separuh bagian hutan lindung. Sedangkan 14 jenis merupakan jenis asli (native) yang tersebar tidak merata. Tingkat penguasaan pohon terhadap habitat berdasarkan luas basal pohon yang didominasi oleh mahoni $(79,219 \%)$ dan pinus $(16,266 \%)$ yang menunjukkan bahwa areal hutan Sapen sebenarnya lebih tepat sebagai hutan produksi monokultur dan beberapa fungsi hutan lindung tidak terpenuhi.

Mahoni merupakan flora yang berasal dari luar ekosistem asli, keberadaannya di Hutan Spaen dikhawatirkan dapat mengganggu keutuhan ekosistem asli kawasan tersebut. Wibisono 2016 menyatakan bahwa tidak banyak jenis tumbuhan bawah yang hidup di lantai hutan bawah tegakan mahoni, tetapi belum ada data yang terukur untuk menggambarkan pengaruh vegetasi tegakan terhadap tumbuhan bawah di Hutan Sapen. Dari uraian tersebut, penting untuk dilakukan suatu penelitian tentang pengaruh jenis tegakan terhadap komposisi dan keanekaragaman tumbuhan bawah di Hutan Sapen Kecamatan Prigen, sehingga nantinya dapat diperoleh data yang dapat membantu dalam penyusunan kebijakan pengelolahan hutan.

\section{METODE PENELITIAN}

\section{Waktu dan Tempat Penelitian}

Penelitian dilakukan pada bulan Juli 2016 di Hutan Sapen, desa Leduk, Kecamatan Prigen, Kabupaten Pasuruan, Provinsi Jawa Timur. Sebelum dilakukan pengambilan sampel, terlebih dahulu dilakukan observasi dan studi pendahuluan.

\section{Bahan dan Alat Penelitian}

Bahan yang digunakan dalam penelitian ini adalah spesies tumbuhan bawah yang ditemukan di bawah tegakan, kantong plastik, kertas label bertali, karet gelang, tali rafia, dan kuadran bambu $2 \times 2$ m. Sedangkan alat yang digunakan adalah alat tulis dan tabel data pengamatan, kompas, klinometer, roll meter, meteran kain, termohigrometer, soil higrometer, soil tester, lup, cetok, bor tanah, kotak plastik, dan kamera.

\section{Teknik Pengambilan Data}

\section{Penentuan Titik Pengamatan}

Luas seluruh Hutan Sapen adalah 20 ha. Dari luas keseluruhan tersebut diambil sampel seluas 10\%. Penetapan ini 
berdasarkan pertimbangan bahwa masingmasing stasiun pengamatan adalah homogen. Dengan demikian, unit sampel penelitian ini adalah 2 ha. Dari 2 ha dibedakan atas 3 stasiun pengamatan berdasarkan jenis tegakan yang ada. Stasiun 1 adalah daerah dengan vegetasi tegakan mahoni. Stasiun 2 adalah daerah dengan vegetasi tegakan pinus. Stasiun 3 adalah daerah tanpa tegakan. Luas setiap stasiun adalah 70x100 $\mathrm{m}^{2}$, sehingga luas total daerah pengamatan adalah $2100 \mathrm{~m}^{2}$. Dalam setiap stasiun pengamatan terdapat 70 plot pengamatan. Pengambilan data dilakukan dengan menggunakan metode analisis vegetasi tumbuhan bawah line transek. Pengamatan dilakukan di setiap plot seluas $2 \times 2 \mathrm{~m}^{2}$ sepanjang jalur line transect.

\section{Pengumpulan Data}

\section{Data Vegetasi Tegakan}

Data yang diambil dari tegakan (pohon) di setiap plot pengamatan meliputi penutupan tajuk (kanopi), lingkar batang, dan tinggi pohon. Pengambilan data penutupan tajuk dilakukan secara kualitatif, dengan cara melakukan penilaian secara visual terhadap penutupan tajuk tiap tegakan. Tingkat penutupan tajuk dikelompokkan mejadi tiga kelas, yaitu besar ( $\geq 75 \%$ ), sedang (50 $-75 \%)$, dan rendah $(\leq 50 \%)$. Data lingkar batang diukur untuk menentukan luas basal area. Tinggi pohon didapatkan dengan melakukan pengukuran terhadap sudut elevasi dan jarak pengamatan terhadap pohon, kemudian dilakukan perhitungan untuk mendapatkan hasil tinggi pohon. Tabel data pengamatan vegetasi tegakan disajikan pada Lampiran 1.

\section{Data Tumbuhan Bawah}

Data tumbuhan bawah yang diambil di setiap titik pengamatan meliputi jenis, jumlah, dan persentase penutupan setiap jenis. Pengambilan data dilakukan dengan mengamati dan menghitung langsung setiap jenis tumbuhan dalam lokasi titik pengamatan. Tabel data pengamatan tumbuhan bawah disajikan pada Lampiran 1.

\section{Data Kondisi Lingkungan}

Pengamatan kondisi lingkungan dilakukan melalui pengamatan faktor abiotik meliputi suhu, pH, kelembaban udara,kelembapan tanah, dan intensitas cahaya. Tabel data pengamatan kondisi lingkungan disajikan pada Lampiran 1.

\section{Analisis Data}

Untuk mengetahui gambaran tentang komposisi jenis dan data ekologi tumbuhan bawah, dilakukan perhitungan terhadap parameter yang meliputi indeks 
nilai penting, indeks dominansi, indeks keanekaragaman jenis, dan indeks kesamaan komunitas.

$H^{\prime}=-\sum_{t=1}^{n}\left(\frac{\mathrm{ni}}{\mathrm{N}} \ln \frac{\mathrm{ni}}{\mathrm{N}}\right)$

\section{Analisis Data Vegetasi Tegakan}

$\mathrm{H}^{\prime}=$ Indeks Keanekaragaman Jenis

Data vegetasi tegakan dianalisis secara deskriptif kualitatif.

$\mathrm{ni}=\mathrm{INP}$ jenis $\mathrm{i}$

$\mathrm{N}=$ Total INP

\section{Analisis Data Tumbuhan Bawah}

\section{a. Indeks Nilai Penting}

\section{c. Indeks Kemerataan Jenis (E)}

Dalam penelitian ini nilai INP yang dihitung hanya pada tingkat tumbuhan bawah dengan rumus:

$$
\mathbf{I N P}=\mathbf{K R}+\mathbf{F R}
$$

Rumus yang digunakan dalam analisis data adalah sebagai berikut:

- Jenis (K)

$E=\frac{H^{\prime}}{\operatorname{in}(S)}$

$\mathrm{E}=$ Indeks Kemerataan Jenis

$\mathrm{H}^{\prime}=$ Indeks Keanekaragaman Jenis

$\mathrm{S}=$ Jumlah jenis

\section{d. Indeks Kekayaan Jenis ( $\left.\mathbf{R}_{1}\right)$}

K

$=\frac{\text { jumlah individu suatu jenis }}{\text { luas petak contoh }(\text { ha })}$ ind

$R 1=\frac{(S-1)}{(\ln (N))}$

/ha

- Jenis Relatif (KR)

$\mathrm{R}_{1}=$ Indeks Kekayaan

$\mathrm{S}=$ Jumlah jenis yang ditemukan

$\mathrm{N}=$ Jumlah total individu

$K R$

$=\frac{\text { kerapatan suatu jenis }}{\text { total kerapatan seluruh jenis }} 100 \%$ IS $=\frac{2 W}{a+b} \times 100 \%$

- Frekuensi (F)

IS $=$ Indeks kesamaan komunitas

F

$\mathrm{W}=$ Jumlah jenis yang sama antara

$=\frac{\text { jumlah plot ditemukan suatu jenis }}{\text { total seluruh plot }}$

komunitas a dan $b$

$\mathrm{a}=$ Jumlah jenis yang terdapat pada

- Frekuensi Relatif (FR)

komunitas a

FR

$=\frac{\text { frekuensi suatu jenis }}{\text { total frekuensi seluruh jenis }} 100 \%$

$\mathrm{b}=$ Jumlah jenis yang terdapat pada

komunitas b

b. Indeks Keanekaragaman Jenis (H')

Analisis Data Kondisi Lingkungan 
Data kondisi lingkungan yang keanekaragaman jenis tumbuhan bawah berupa hasil pengukuran faaktor abiotik pada hutan.

meliputi suhu, $\mathrm{pH}$, kelembaban udara,

Hasil pengamatan menunjukkan kelembapan tanah, dan intensitas cahaya bahwa jenis tegakan di hutan Sapen dianalisis secara deskriptif kualitatif.

\section{HASIL DAN PEMBAHASAN}

Jenis tegakan dengan tingkat mempengaruhi struktur dan komposisi jenis tumbuhan bawah dikarenakan kondisi lingkungan mikro di bawah penutupan tajuk yang berbeda akan membentuk iklim mikro yang berbeda pada lantai hutan. Sementara, perbedaan kecepatan dekomposisi serasah pada tiap jenis tegakan mengakibatkan suplai bahan organik di dalam tanah juga berbeda, sehingga kualitas tanah pada tiap jenis tegakan juga berbeda. Hal ini dapat tegakan berbeda sebagai akibat perbedaan penutupan tajuk. Jumlah total spesies yang ditemukan di tiga stasiun pengamatan adalah 137 spesies dari 43 famili. 80 spesies dari 37 famili di stasiun 1 (tegakan mahoni), 75 spesies dari 25 famili di stasiun 2 (tegakan pinus), dan 72 spesies dari 31 famili di stasiun 3 (tanpa tegakan) berpengaruh terhadap komposisi dan

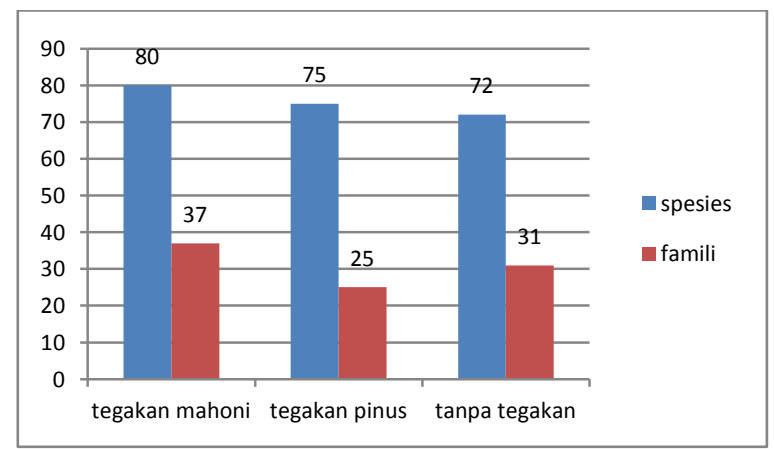

Gambar 3.1. Histogram Komposisi Jenis pada tiga stasiun pengamatan

Indeks nilai penting (INP) suatu (2013) mengemukakan bahwa jenis yang jenis menggambarkan tingkat dominan adalah jenis yang dapat dominasinya terhadap jenis lain dalam memanfaatkan lingkungan yang ditempati suatu komunitas. Jenis-jenis yang secara efisien dibanding jenis lain dalam mempunyai INP tertinggi berpeluang tempat yang sama. Jenis yang mempunyai lebih besar untuk dapat mempertahankan INP lebih tinggi akan lebih stabil, dilihat pertumbuhan dan kelestarian jenisnya. dari sisi ketahanan jenis dan Smith (1977) dalam Mawazin dan Atok pertumbuhannya. Sutisna (1981) dalam 
Mawazin dan Atok (2013) semakin stabil. INP lima tumbuhan teratas mengemukakan semakin tinggi INP suatu disajikan pada Tabel 3.1, 3.2, dan 3.3. jenis, maka keberadaan jenis tersebut

Tabel 3.1 Indeks Nilai Penting Lima Urutan Teratas Tumbuhan Bawah Stasiun 1 (Tegakan Mahoni)

\begin{tabular}{|r|l|l|l|c|r|r|}
\hline NO & $\begin{array}{l}\text { NAMA } \\
\text { LOKAL }\end{array}$ & \multicolumn{1}{|c|}{ NAMA ILMIAH } & \multicolumn{1}{|c|}{ FAMILI } & KR & FR & INP \\
\hline 1 & - & Paspalum conjugatum & Poaceae & 17,19939 & 4,545465 & 21,74486 \\
\hline 2 & - & Athyrium sp & Polypodiaceae & 10,59361 & 7,102289 & 17,6959 \\
\hline 3 & Teh-tehan & Eupaterium riparium & Asteraceae / Compositae & 9,223744 & 5,113648 & 14,33739 \\
\hline 4 & Bubutan & $\begin{array}{l}\text { Pasphalum } \\
\text { commersonii }\end{array}$ & Poacceae / Graminiae & 9,223744 & 2,840916 & 12,06466 \\
\hline 5 & $\begin{array}{l}\text { Kacang- } \\
\text { kacangan }\end{array}$ & Centrocema pubescens & $\begin{array}{l}\text { Papilonaceae / } \\
\text { Leguminoceae / Fabaceae }\end{array}$ & 3,926941 & 5,39774 & 9,324681 \\
\hline
\end{tabular}

Tabel 3.2 Indeks Nilai Penting Tumbuhan Bawah

Stasiun 2 (Tegakan Pinus)

\begin{tabular}{|r|l|l|l|l|r|r|}
\hline NO & \multicolumn{1}{|c|}{$\begin{array}{c}\text { NAMA } \\
\text { LOKAL }\end{array}$} & \multicolumn{1}{|c|}{ NAMA ILMIAH } & FAMILI & KR & FR & INP \\
\hline 1 & Bubutan & $\begin{array}{l}\text { Pasphalum } \\
\text { commersonii }\end{array}$ & Poacceae / Graminiae & 71,433 & 6,216218 & 77,649 \\
\hline 2 & $\begin{array}{l}\text { Alang- } \\
\text { alang }\end{array}$ & Imperata cylindrica & Poacceae / Graminiae & 10,369 & 1,351352 & 11,720 \\
\hline 3 & $\begin{array}{l}\text { Kacang- } \\
\text { kacangan }\end{array}$ & $\begin{array}{l}\text { Centrocema } \\
\text { pubescens }\end{array}$ & $\begin{array}{l}\text { Papilonaceae / } \\
\text { Leguminoceae / } \\
\text { Fabaceae }\end{array}$ & 0,716 & 5,135137 & 5,851 \\
\hline 4 & Kolonjono & $\begin{array}{l}\text { Pennisetum } \\
\text { purpureum }\end{array}$ & Poacceae / Graminiae & 1,922 & 3,783785 & 5,706 \\
\hline 5 & Gajahan & Axonopus enapositus & Poacceae / Graminiae & 4,071 & 1,621622 & 5,692 \\
\hline
\end{tabular}

Tabel 3.3 Indeks Nilai Penting Tumbuhan Bawah

Stasiun 3 (Tanpa Tegakan)

\begin{tabular}{|c|c|c|c|c|c|c|}
\hline NO & $\begin{array}{l}\text { NAMA } \\
\text { LOKAL }\end{array}$ & NAMA ILMIAH & FAMILI & KR & FR & INP \\
\hline 1 & Suket jarem & $\begin{array}{l}\text { Desmodium } \\
\text { triflorum }\end{array}$ & Papilonaceae & 18,506 & 4,356 & 22,862 \\
\hline 2 & Alang-alang & Imperata cylindrica & Poacceae / Graminiae & 15,799 & 4,174 & 19,973 \\
\hline 3 & Gajahan kecil & Axonopus sp & Poacceae / Graminiae & 8,291 & 3,63 & 11,921 \\
\hline 4 & Juwawutan & Setaria $s p$ & Poacceae / Graminiae & 7,424 & 2,178 & 9,602 \\
\hline 5 & $\begin{array}{l}\text { Puteri malu / } \\
\text { Kumis kucing }\end{array}$ & Mimosa pudica & $\begin{array}{l}\text { Mimosaceae / } \\
\text { Leguminoceae / } \\
\text { Fabaceae / }\end{array}$ & 4,21 & 4,356 & 8,566 \\
\hline
\end{tabular}


Indeks keanekaragaman jenis adalah parameter yang sangat berguna untuk membandingkan dua komunitas, terutama untuk mempelajari pengaruh gangguan biotik, untuk mengetahui tingkatan suksesi, atau kestabilan suatu komunitas. Keanekaragaman jenis ditentukan dengan menggunakan rumus Indeks

keanekaragaman tergolong tinggi. Pada indeks kemerataan jenis (E'), $E^{\prime}<0.3$ menunjukkan kemerataan jenis tergolong rendah, $E^{\prime}=0.3-0.6$ kemerataan jenis tergolong sedang, dan $E^{\prime}>0.6$ kemerataaan jenis tergolong tinggi. Sedangkan pada indeks kekayaan jenis $\left(\mathrm{R}_{1}\right)$, berdasarkan Magurran (1988) Keanekaragaman Shannon-Wiener. besaran $\mathrm{R}_{1}<3.5$ menunjukkan kekayaan Besaran $\mathrm{H}^{\prime}<1.5$ menunjukkan jenis yang tergolong rendah, $\mathrm{R}_{1}=3.5-$ keanekaragaman jenis tergolong rendah, 5.0 menunjukkan kekayaan jenis $\mathrm{H}^{\prime}=1.5-3.5$ menunjukkan tergolong sedang dan $\mathrm{R}_{1}$ tergolong tinggi keanekaragaman jenis tergolong sedang jika > 5.0. Data $\mathrm{H}^{\prime}, \mathrm{E}^{\prime}$, dan $\mathrm{R}_{1}$ disajikan dan $\mathrm{H}^{\prime}>3.5$ menunjukkan dalam gambar 3.2.

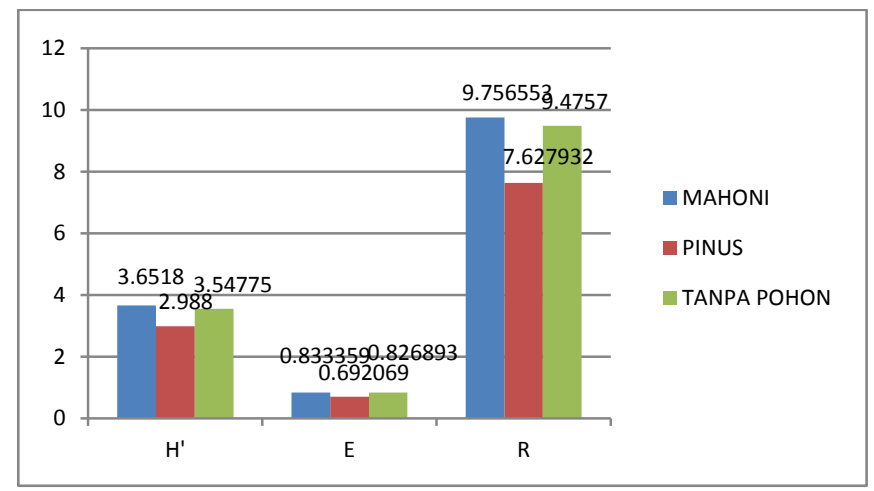

Gambar 3.2 Diagram H', E, dan R Tiga Stasiun Penelititan

\section{Indeks Kesamaan Komunitas (Is)}

Indeks kesamaan komunitas (Is) mendekati 100\% keadaan tegakan yang adalah parameter yang digunakan untuk dibandingkan mempunyai kesamaan yang mengetahui kesamaan relatif dari semakin tinggi. Data Is disajikan pada komposisi jenis dan struktur antara dua Tabel 3.4. tegakan yang dibandingkan. Semakin

Tabel 3.4. Data Indeks Kesamaan Komunitas

\begin{tabular}{|c|c|c|}
\hline Mahoni-Pinus & Pinus-Tanpa Tegakan & Mahoni-Tanpa Tegakan \\
\hline $48,68 \%$ & $60,275 \%$ & $36 \%$ \\
\hline
\end{tabular}


Data kondisi lingkungan (faktor Secara rinci data disajikan pada Lampiran abiotik) meliputi suhu, $\mathrm{pH}$, kelembapan tanah, kelembapan udara, dan intensitas 5. Sedangkan rekapitulasinya disajikan cahaya diambil dengan tiga kali ulangan. pada tabel 3.5.

Tabel 4.6. Data Pengamatan Kondisi Lingkungan Stasiun 1 (Tegakan Mahoni)

\begin{tabular}{|l|l|l|c|c|c|}
\hline \multicolumn{1}{|c|}{ Stasiun } & $\begin{array}{l}\text { Suh } \\
\mathbf{u} \\
\left({ }^{\mathbf{0}} \mathbf{C}\right)\end{array}$ & $\begin{array}{l}\text { pH } \\
\text { 1. Mahoni }\end{array}$ & $\begin{array}{c}\text { Kelembapa } \\
\mathbf{n} \text { tanah } \\
(\boldsymbol{\%})\end{array}$ & $\begin{array}{c}\text { Kelembapa } \\
\mathbf{n} \\
\text { udara(\%) }\end{array}$ & $\begin{array}{c}\text { Intensitas } \\
\text { cahaya } \\
(\text { lux })\end{array}$ \\
\hline 2. Pinus & $\begin{array}{l}\mathbf{3 , 9} \\
\mathbf{6}\end{array}$ & $\mathbf{8 9 , 3}$ & $\mathbf{7 2 , 3}$ & $\mathbf{2 8 1 3 , 3}$ \\
& $\mathbf{6}$ & $\begin{array}{l}\mathbf{6 , 2} \\
\mathbf{6}\end{array}$ & $\mathbf{7 5}$ & $\mathbf{6 6 , 3}$ & $\mathbf{1 5 7 0 0}$ \\
\hline 3. Tanpa tegakan & $\mathbf{3 2 , 3}$ & $\mathbf{6 , 1}$ & $\mathbf{7 1 , 6}$ & $\mathbf{6 6 , 6}$ & $\mathbf{4 5 3 6 6 , 6}$ \\
\hline
\end{tabular}

Tegakan mahoni mempunyai percabangan yang banyak dengan tajuk yang lebat dan lebar, sehingga intensitas cahaya yang masuk di lantai hutan menjadi rendah (2813,3 lux). Hal ini mempengaruhi besarnya suhu dan kelembaban udara, dimana suhu udara di bawah tegakan mahoni tercatat paling rendah $\left(27,33^{\circ} \mathrm{C}\right)$ dibandingkan tegakan lainnya, kelembaban udara tercatat mencapai $72,3 \%$, dan kelembapan tanah mencapai $89,3 \%$.

$\mathrm{pH}$ tanah di tiga stasiun pengamatan cenderung asam, terutama pada stasiun 1 . Hardjowigeno (2003) menyatakan bahwa $\mathrm{pH}$ tanah yang sangat masam menyebabkan sulitnya unsur hara diserap tanaman. Hal ini karena adanya unsurunsur beracun dan mengganggu perkembangan
Mikroorganisme berperan dalam proses pembusukan/dekomposisi serasah, sehingga jika perkembangan mikroorganisme tergaanggu maka pembusukan serasah juga akan terganggu. Pada stasiun 1, tumbuhan bawah yang paling mendominasi adalah Pasphalum conjugatum. Hal ini senada dengan hasil penelitian Hilwan (2013), yang menyatakan bahwa jenis tumbuhan bawah yang ditemukan pada tegakan trembesi ( $\mathrm{pH}$ tanah asam) merupakan jenis-jenis yang memiliki sifat toleransi terhadap tanah asam, diantaranya adalah jenis $P$. conjugatum, $P$. javanica, $P$. distichum, dan Nreynaudia. Jenis P.conjugatum dan S.torvum memiliki tingkat tolerasi tinggi terhadap faktorfaktor lingkungan yang berpengaruh, terutama naungan dan tanah. 
Pada stasiun 2, tumbuhan bawah yang paling mendominasi adalah Pasphalum commersonii. Tumbuhan ini berasal dari genus yang sama dengan stasiun 1, yaitu pasphalum. Segala kebutuhan yang mendukung hidupnya tidak jauh berbeda dengan Pasphalum conjugatum, seperti pada stasiun 1, misalnya saja $\mathrm{pH}$ tanah yang cenderung asam. Selain itu juga terdapat Imperata cylindrica (alang-alang). Alang-alang merupakan jenis tumbuhan pionir yang banyak tumbuh pada lahan yang habis terbakar, sangat toleran terhadap faktor lingkungan yang ekstrim seperti kekeringan dan unsur hara yang miskin, namun tidak toleran terhadap genangan dan naungan.

Alang-alang dapat menekan pertumbuhan vegetasi lainnya. Sedangkan jenis-jenis vegetasi lain kurang dapat berkompetisi dalam pemenuhan kebutuhan unsur hara dibandingkan dengan alang-alang. Hal ini seperti diungkapkan oleh McIlroy (1977) dalam Octavia (2004), bahwa kelimpahan suatu jenis dipengaruhi oleh beberapa faktor seperti: persistensi (daya tahan), agresivitas (daya saing), kemampuan tumbuh kembali akibat manipulasi lahan, sifat tahan kering dan tahan dingin, penyebaran produksi musiman, kemampuan menghasilkan biji, kesuburan tanah, serta iklim terutama curah dan distribusi hujan.

Pada stasiun 3, tumbuhan bawah yang paling mendominasi adalah Desmodium triflorum (suket jarem) dan Imperata cylindrica (alang-alang). Keduanya merupakan spesies yang hidup baik di lingkungan dengan intensitas cahaya tinggi. Intensitas cahaya paling tinggi tercatat pada stasiun 3 (tanpa tegakan) (45366,6 lux), hal ini disebabkan tidak ada yang menghalangi sampainya cahaya matahari ke lantai hutan (tanah). Sebagai akibatnya suhu udara di stasiun tanpa tegakan tercatat paling tinggi $\left(32,3^{\circ} \mathrm{C}\right)$ dibanding tegakan lain. Pada kondisi ini, alang-alang mampu tumbuh dominan serta menghambat jenis-jenis tumbuhan bawah yang lain. Filter dan Hay (1998) dalam Setyawan (2006) menyatakan bahwa salah satu kondisi lingkungan yang paling berpengaruh terhadap pertumbuhan tumbuhan di bawah tegakan antara lain cahaya matahari atau naungan.

Tingkat keragaman jenis tumbuhan bawah tertinggi dari hasil penelitian terdapat pada tegakan mahoni, dan terendah pada tegakan pinus. Tegakan ini mempunyai tajuk yang lebar sehingga mampu menciptakan lingkungan mikro 
seperti suhu dan kelembaban tanah yang sesuai dengan pertumbuhan berbagai jenis tumbuhan bawah, khususnya jenis-jenis yang adaptif dengan kelembaban tinggi.

Stratum tumbuhan bawah yang terdiri atas lapisan-lapisan semak dan herba, dan dapat menjadi lebat jika terjadi pembukaan tajuk (Mc Naughton dan Wolf, 1992). Seharusnya hal ini terjadi pada stasiun 3 (tanpa tegakan). Tetapi karena adanya aktivitas manusia (mengambil rumput untuk makanan ternak) maka kondisi tersebut tidak terjadi. Diperkirakan, jika tidak akda campur tangan aktivitas manusia di stasiun 3, maka tingkat keanekaragaman jenisnya akan lebih tinggi dari pada stasiun yang lainnya.

Beberapa jenis tumbuhan di lokasi penelitian, seperti mahoni, pinus, dan alang-alang diduga menghasilkan senyawa alelopati, yang berpengaruh pada keragaman jenis tumbuhan bawah. Seperti diungkapkan oleh Samingan (1988) dalam Kunarso dan Fatahul (2013), bahwa jenisjenis tersebut dapat menghasilkan senyawa kimia yang bersifat menghambat pertumbuhan individu tumbuhan lainnya. Tingkat kekerasan dari sifat penghambatan tersebut bergantung pada jenis dan iklim serta cara pengaturan dari tumbuhan penghasil ke lingkungan, sehingga faktor-faktor lingkungan pada suatu penggunaan lahan tidak begitu menampakkan pengaruhnya. Salah satu pengaruh alelopati adalah menyebabkan akumulasi nitrogen terhambat, yang pada akhirnya akan menghambat pertumbuhan tanaman lain karena tidak dapat menyerap unsur $\mathrm{N}$ secara optimal.

Hilwan (1993) dalam hasil penelitiannya menyatakan bahwa senyawa organik dalam serasah P.merkusii yang menghambat pertumbuhan jagung (zat alelopati) adalah senyawa dari kelompok monoterpen yaitu berupa $\alpha$-pinene $\operatorname{dan} \beta$ pinene. Diperkirakan bahwa efek alelopati serasah tersebut bersifat tidak langsung yaitu terlebih dahulu dengan mempengaruhi sifat kimia tanah. Hal ini juga yang di duga menjadi penyebab rendahnya keragaman jenis tumbuhan bawahnya $(2,988)$ dibandingkan dengan tegakan yang lain. Selain itu juga karena adanya dominasi rumput Bubutan dan Alang-alang.

Tingkat keanekaragaman yang tinggi mempengaruhi kestabilan jenis dalam suatu ekosistem. Suatu jenis yang memiliki tingkat kestabilan yang tinggi mempunyai peluang lebih besar untuk mempertahankan kelestariann jenisnya. Untuk menilai kestabilan jenis dalam suatu komunitas dapat mengacu pada 
indeks kemerataan jenis (E'). Semakin tinggi nilai E' maka keanekaragaman jenis dalam komunitas semakin stabil. Kemerataan jenis pada tiga stasiun penelian termasuk kategori tingg, dengan E' tertinggi pada stasiun 1 dan terendah pada stasiun 2. Hal ini selaras dengan data keanekaragamn jenis $\left(H^{\prime}\right), \quad$ dimana keanekaragaman jenis di stasiun 1 memang paling tinggi, disusul stasiun 3, kemudian stasiun 2.

Indeks kekayaan species yaitu jumlah total species dalam satu komunitas, tergantung dari ukuran sampel (dan waktu yang diperlukan untuk mencapainya), ini dibatasi sebagai indeks komperatif. Kekayaan spesies paling tinggi ada pada stasiun 1, kemudian stasiun 3, dan stasiun 2. Hal ini senada dengan data $\mathrm{H}^{\prime}$.

Tumbuhan bawah memiliki banyak manfaat bagi lingkungan diantaranya adalah dapat membantu menjaga agregat tanah agar tidak mudah lepas dan tererosi oleh air hujan maupun aliran permukaan. Suksesi sekunder yang terjadi pada daerah hutan hujan yang diusahakan, lalu ditinggalkan, pertumbuhannya akan dimulai dengan vegetasi rumput dan semak kecil seperti yang ditemukan pada lokasi penelitian yaitu P. conjugatum. Selain itu, tumbuhan bawah dapat berperan sebagai sumber obat-obatan, sumber plasma nutfah, pakan ternak dan satwa hutan, serta manfaat lainnya yang belum diketahui. Oleh karen itu, pelestarian keanekaragaman tumbuhan bawah sangat penting dilakukan, karena termasuk kekayaan alam sebagai salah satu komponen yang dapat menjaga keseimbangan ekosistem hutan.

\section{KESIMPULAN}

1. Jenis tegakan di Hutan Sapen berpengaruh terhadap struktur dan komposisi jenis tumbuhan bawah (Tabel 4.5). Jumlah total spesies yang ditemukan di tiga stasiun pengamatan adalah 137 spesies dari 43 famili. 80 spesies dari 37 famili di stasiun 1 (tegakan mahoni), 75 spesies dari 25 famili di stasiun 2 (tegakan pinus), dan 72 spesies dari 31 famili di stasiun 3 (tanpa tegakan).

2. Keanekaragaman tumbuhan bawah di hutan Blok Sapen bedasarkan indeks keanekaragaman (H') tertinggi ada pada stasiun 1 (tegakan mahoni) $(3,6518)$, kemudian stasiun 3 (tanpa tegakan) (3,54775), dan stasiun 2 (tegakan pinus)(2,988).

3. Struktur dan komposisi tumbuhan bawah Berdasarkan INP, pada stasiun 1 lima urutan teratas tumbuhan bawah 
yang mendominasi adalah Paspalum conjugatum, Athyrium sp, Pasphalum commersonii, Centrocema pubescens, dan Adiantum sp. Pada stasiun 2 adalah Pasphalum commersonii, Imperata cylindrica, Centrocema pubescens, Pennisetum purpureum, dan Axonopus enapositus. dan pada stasiun 3 adalah Desmodium triflorum, Imperata cylindrica, Axonopus sp, Juwawutan, dan Mimosa pudica.

4. Jenis tegakan yang berbeda mempengaruhi iklim mikro yang berbeda pada lantai hutan, menyebabkan kondisi lingkungan $(\mathrm{pH}$, suhu, kelembapan tanah, kelembapan udara, dan intensitas cahaya) berbeda. Selain itu zat alelopati dan kecepatan dekomposisi serasah, juga berperan serta dalam menentukan komposisi dan keanekaragaman tumbuhan bawah.

\section{Saran}

1. Kegiatan penelitian dapat dilakukan dengan sampel lokasi yang lebih luas, sehingga akan lebih banyak spesies yang dapat diidentifikasi.

2. Penelitian dapat dilakukan dengan waktu yang lebih lama, dengan pengamat yang sama (1 orang), sehingga tidak ada perbedaan interpretasi (misalnya dalam menghitung jumlah spesies, menentukan persentase penutupan, dll), karena data seperti tersebut sangat bergantung kepada interpretasi pengamat.

3. Penelitian lanjutan dapat dilakukan untuk menentukan masing-masing manfaat dari keanekaragaman tumbuhan bawah yang telah teridentifikasi, misalnya perannannya sebagai tumbuhan obat, atau peran ekologisnya di lokasi tumbuhan tersebut berada, budidaya tumbuhan bawah yang bermanfaat, pengendalian tumbuhan bawah yang berperan sebagai gulma, dan lain-lain.

\section{DAFTAR PUSTAKA}

Arifin, A. (2001). Hutan, Hakikat dan Pengaruhnya terhadap Lingkungan. Yayasan Obor Indonesia. Jakarta

Dahir. (2012). Struktur dan Komposisi Vegetasi Tumbuhan Bawah (Semak, Herba, Dan Rumput) Dengan Variasi Ketinggian, Pada Naungan Tectona Grandis L.F, Di Desa Selopamioro, Imogiri, Bantul, Yogyakarta. Skripsi Tidak Diterbitkan. Uniersitas islam negeri sunan kalijaga Yogyakarta, (online) (digilib.uin-suka.ac.id), diakses pada 13 Juli 2016.

Djarwaningsih. (2010). Karakterisasi Tipe Vegetasi dan Keanekaragaman Jenis Flora/Jamur di Cagar Alam Gunung Tukung Gede, Serang- 
Banten. Laporan Akhir Program Insentif Peneliti dan Perekayasa LIPI Tahun 2010. Tidak diterbitkan.

Hilwan, iwan. (1993). Produksi, laju dekomposisi, dan Pengaruh Alelopati Serasah Pinus merkusii Jungh. et De Vriese dan Acacia mangium Wild. di Hutan Gunung Walat, Sukabumi, Jawa Barat. Tesis tidak diterbitkan. Institut Pertanian Bogor.

Hilwan, Iwan., Dadan Mulyana., dan Weda Gelar Pananjung. (2013). Keanekaraaman Jenis Tumbuhan Bawah pada Tegakan Sengon Buto (Enterolobium cyclocarpum Griseb.) dan Trembesi (Samanea saman Merr.) di Lahan Pasca Tambang Batubara PT Kitadin, Embalut, Kutai Kartanagara, Kalimantan Timur. Jurnal Silvikultur Tropika Vol. 04 No. 01 April 2013, Hal. 6 - 10 ISSN: 2086-8227.

Irwan, Z.D. (2003). Ekosistem Komunitas dan Lingkungan. Bumi Aksara. Jakarta.

Kunarso, Adi dan Fatahul Azwar. 2012. Keragaman Jenis Tumbuhan Bawah Pada Berbagai Tegakan Hutan Tanaman Di Benakat, Sumatera Selatan. Jurnal Penelitian Hutan Tanaman Vol. 10 No. 2, Juni 2013: 85-98 ISSN: 1829-6327 Terakreditasi No.: 482/AU2/P2MILIPI/08/2012.

Mawazin, dan Atok Subiakto. 2013. Keanekaragaman dan Komposisi Jenis Permudaan Alam Hutan Rawa Gambut Bekas Tebangan di Riau. Forest Rehabilitation Journal
Vol. 1 No. 1, September 2013: 5973.

Octavia. D., F.Azwar,M.A. Qirom., danS. Andriyani. 2004. Potensi Pakan Banteng (d'Alton) di Areal Savana Seksi Wilayah Bekol Taman Nasional Baluran. Laporan Kegiatan. Balai Taman Nasional Baluran. Departemen Kehutan an. (Tidak diterbitkan).

Setyawan AD, S Setyaningsih, dan Sugiyarto 2006. Pengaruh Jenis dan Kombinasi Tanaman Sela Terhadap Diversitas dan Biomassa Gulma di Bawah Tegakan Sengon (Paraserienthes falcataria L. Nielsen) di Resort Pemangkuan Hutan Jatirejo Kediri. Biosmart. Vol. 8:1. April 2006 Hlm 27-32.

Soerianegara I dan A Indrawan. 2008. Ekologi Hutan Indonesia. Bogor. Laboratorium Ekologi Hutan. Fakultas Kehutanan. Institut Pertanian Bogor.

Soerianegara I dan A Indrawan. 2008. Ekologi Hutan Indonesia. Bogor. Laboratorium Ekologi Hutan. Fakultas Kehutanan. Institut Pertanian Bogor.

Wibisono, Mulyono dan Syukur, S.A. 2016. BASELINE STUDY: Keanekaragaman Hayati Flora dan Funa di Hutan Sapen Leduk Kec. Prigen- Kab.Pasuruan. Pasuruan: Yudharta Press. 